DOI: 10.2478/atd-2021-0016

\title{
Metaphoric Perceptions of Preschool Teachers towards Inclusive Education
}

\author{
Ayhan Bulut* \\ Received: August 12, 2020; received in revised form: December 27, 2020; \\ accepted: January 8, 2021
}

\begin{abstract}
:
Introduction: The purpose of this study is to determine the metaphorical perceptions of preschool teachers in regard with the concept of inclusive education.

Methods: In this study, phenomenology design, which is one of the qualitative research methods, was used. The study group of this research consists of preschool teachers, who have students either received or currently receiving inclusive education in their classrooms. In the research, the content analysis was conducted in order to analyze the data obtained from preschool teachers.
\end{abstract}

Results: Of the 113 preschool teachers participated in the study, the answers given by 101 teachers to the research question were included in the evaluation. At the end of the evaluation phase, it was determined that preschool teachers developed a total of 53 different metaphors in regard with the concept of inclusive education and 53 valid metaphors developed by preschool teachers were analyzed by gathering them under 9 different categories according to their common characteristics.

Discussion: In accordance with the data obtained from the research, the distribution of metaphors developed by preschool teachers regarding the concept of "inclusive education" by categories is observed as follows: inclusive education as the riches of nature, inclusive education depending on the soil and inclusive education as work and living areas. However, the metaphor of the "rainbow" draws attention as the most developed metaphor for inclusive education in all categories by the participants.

Limitations: Due to the COVID-19 virus pandemic, data were collected from participants using an online interview form.

Conclusion: The study also concluded that the perceptions of the participants towards inclusive education were generally positive.

Key words: preschool, inclusive education, metaphor, perception.

\footnotetext{
* Ayhan Bulut, Bayburt University, Faculty of Education, Bayburt, Turkey; ayhanbulut@bayburt.edu.tr
} 


\section{Introduction}

Resilient individuals are able to overcome adverse situations, they actively seek and use help from their social environment and take advantage of various social relationships available to them (Barnová \& Tamášová, 2018). Inclusive education refers to special education practices based on the principle that individuals, who need special education, should continue their education both in public and private preschools, primary and secondary education institutions as well as non-formal education institutions with their peers, who have no disabilities (Batu \& Kırcaali-İftar, 2007). Guralnick (2001) and Salisbury (1990) define inclusion as a planned, developed and conceptualized value that clearly demonstrates the education and development of young children. Inclusive education refers to an educational model where in students with special needs attend general education classes and receive appropriate special education support (Bender, Vail, \& Scott, 1995). The main concept of inclusion is providing the special education services to individuals, who need special education, ensuring that they attend the same school and classroom with their peers at the same age (York \& Tundidor, 1995; as cited in Kargın, 2004). Today, the concept of inclusive education has become widespread due to the need for equal opportunities in education, full participation, independent life and economic self-efficacy (Cohen, 2009; Turnbull et al., 2013; as cited in Gürgür \& Hasanoğlu-Yazçayır, 2019). There are researches demonstrating the effective factors in the expansion of inclusive education and its positive outcomes (Tideman, 2015; Mitchell, 2008; Corbett, 2001).

As a result of the developments in human rights and special education fields all over the world in the 1960s, as the idea that children with special needs attend general education schools with their peers become widespread, these rights were secured with the agreements signed in the international area. This concept, which was initially called as inclusive education in the early days, has also started to be expressed with the concept of integration (ERG, 2011). The Special Education World Conference was held in Salamanca, attended by more than 300 people from 92 states and 25 international organizations in 1994. The conference aimed to develop the integration approach in line with the goal of "education for all" and take the necessary political steps to ensure that schools serve all children, especially children with special needs (UNESCO, 1994; as cited in Dede, 1996). 10 years after UNESCO's "education for all" movement started in 1990, the World Education Forum was organized in Dakar, Senegal in order to evaluate what was carried out during this period. In the forum, it was determined that the goal of "education for all" could not be achieved at the desired level, The Dakar Framework for Action, which includes the things to be done to achieve this goal, was adopted. The framework governments have been obliged to provide quality basic education for everyone until 2015 (Inclusion International, 2009). The right to receive education through integration (inclusion) is guaranteed in international law with the 24th article of the United 
Nations Convention on the Rights of Persons with Disabilities (CRPD), which was adopted in the United Nations General Assembly in 2006, (CRPD, 2011). It is possible to come across studies that can be shown as remarkable in terms of inclusive (integration) education in the world. Early special education services, which began in Sweden in 1952 with the visits of the families of children with developmental retardation by nurses, were further expanded in 1981 with the prevention programs carried out as a result of the announcement of "Swedish National Health and Welfare". In 2001, children with disabilities were provided with education in a preschool institution, where integration studies were applied (Choi, 2002; as cited in Pinar-Sazak, 2006). In Germany, while debates about equal education opportunities continued in the 1960s and 1970s, initiatives for special education and early childhood special education first started for children with speech disorders and hearing impairments (Opp \&Thurmair, 1993). With the laws that came into force in Italy in 1971, England in 1974, America and France in 1975 and Norway in 1976, it was legally accepted that students with special needs should be educated in general education classes with their peers (OECD, 1995; as cited in Sucuoğlu \& Kargın, 2010). Even though preschool inclusion has been implemented worldwide for a long time, in Turkey, the efforts in regard with laws and regulations about the issue, support programs regarding the preschool inclusion and teaching in the natural environment have been observed in recent years (Diken et al., 2016).

Preschool education is defined as an educational process including childhood years from birth to the beginning of primary school that provides rich stimulating environment opportunities suitable for the mental characteristics and development levels of children and directs their development in the best way in line with the cultural values of the society (Oğuzkan \& Oral, 1995). Inclusive education has a great importance in preschool education, which is one of the most critical periods of life in terms of gaining basic communication skills and accelerating the development of children with special needs in order to facilitate their integration into society in the following years (Gampel, Gottlieb, \& Harrison, 1974; Metin, 1992). With the inclusion programs implemented in this period, the child with special needs will have the opportunity to experience the gains he/she has acquired with his/her peers and he/she will take his/her peers as an example with the friendships established (Shickedanz, 1994; as cited in Özdemir, 2010).

Providing education to individuals with special needs during preschool period allows their developmental disabilities to be supported at an early age. Preschool education is very important in terms of creating significant differences in the growth and development of the child with special needs. Education provided in these years improves the mental and social development of the children and helps reducing their behavioural problems (Zigmond, Kloo, \& Volonino, 2009; Aral, 2011; Koçyiğit, 2015). Besides, the participation of a child with special 
needs in the group of friends at school contributes to the development of the child's self-confidence (Karadeniz, 2002).

As in all over the world, the importance given to inclusive education during a preschool level in Turkey is increasing each passing day. Undoubtedly, the quality of education provided to children with special needs during preschool education is closely related to how teachers perceive and shape the concept of inclusive education in their minds. In this respect, teachers are the ones who will add spirit and give life to the studies related to inclusive education. Therefore, revealing the metaphorical perspectives and perceptions of teachers on the subject has become the main topic of the research. It is very important for teacher candidates to use metaphors to get to know and explain themselves (Tannehill \& MacPhail, 2014). Metaphor is a way of defining an event, concept, or phenomenon with the same characteristics by comparing it with another event, concept and phenomenon (Wehmeier, 1993). Metaphor provides a powerful way to understand experiences and explore roles in experiences (Goldstein, 2005). In other words, metaphor is a type of figurative language used to compare objects with similar properties (Stockton, 2017). As Lakoff and Johnson (2010) point out, metaphor has been seen not only as linguistic, but also as a much broader concept that affects thinking and action processes of people. Metaphors are also mental tools that individuals can use to understand and explain abstract and complex facts (Drakenberg \& Malmgren, 2012).

Even though no other research has been found at the national and international level examining the metaphoric perceptions of teachers towards the concept of inclusive education in preschool education, some studies using metaphors in preschool education (Duran \& Dağlıŏglu, 2017; Talas, 2017; Uçuş, 2016; Zembat, İlknur- Tunçeli, \& Akşin, 2015; Giren \& Durak, 2015; Hannu et al., 2012; Salisbury, 1991; Odom \& McEvoy,1990) were found in the relevant literature both nationally and internationally.

The aim of this study is to determine the metaphorical perceptions of preschool teachers regarding the concept of inclusive education. Accordingly, answers to the following questions were sought.

- Which metaphors do the preschool teachers usually use in order to explain their perceptions about the concept of inclusive education?

- Under which categories are the metaphors of preschool teachers regarding the concept of inclusive education gathered together according to their common characteristics?

\section{Method}

In this study, which examined the metaphors of preschool teachers regarding the concept of inclusive education, phenomenology pattern, which is one of the qualitative research approaches, was employed. The purpose of using this pattern is that it creates a suitable basis for focusing on the facts that we are aware of in our daily lives but do not have an in-depth and detailed 


\section{Acta Educationis Generalis \\ Volume 11, 2021, Issue 2}

understanding. However, these facts may appear in various ways, such as events, experiences, perceptions, concepts and situations (Büyüköztürk et al., 2011; Yıldırım \& Şimşek, 2011). The main purpose of phenomenology studies is to take personal experiences related to a phenomenon to a more general level (Creswell, 2007).

\subsection{Study group}

The study group of this research consists of preschool teachers, who have students either received or currently receiving inclusive education in their classrooms, working in public schools in a province in Turkey in the academic year 2019-2020.

\subsection{Data collection}

While creating the data collection tool of the research, the relevant studies using metaphors as a tool to reveal the perceptions of individuals have been examined (Yazıc1 et al., 2018; Duran \& Dağlığlu, 2017; Uçuş, 2016; Akgün, 2016; Zembat, Tuçeli, \& Akşin, 2015; Guerrero \& Villamil, 2002). A semi-structured form that is written in the format of "Inclusive education is similar to/like ....... because......" was given to preschool teachers in order to collect their metaphors regarding the concept of inclusive education. Preschool teachers were asked to write their metaphors about the concept of inclusive education with their reasons. In the studies, where metaphor is used as a research tool, the relationship between the subject and the source of the metaphor is tried to be determined by the word "like", while the meaning and reason attached to this metaphor is tried to be explained by the word "because" (Saban, 2008). The data obtained from here constituted the main data source of the research.

\subsection{Data analysis}

In the research, the content analysis was conducted in order to analyze the data obtained from preschool teachers. The main operations performed in the content analysis are gathering data that are similar in various aspects under certain concepts and themes, organizing and interpreting this data in a way that the readers can easily understand (Yıldırım \& Şimşek, 2011). In this process, the metaphors obtained from preschool teachers were evaluated by taking various stages used by Saban (2009) into account. First, the metaphors developed by preschool teachers in regard with inclusive education were arranged in alphabetical order at the naming stage. Then, in the second stage, which is the classification/screening phase, the relationship between the subject and the source of the metaphor was examined by reviewing each metaphor separately and attention was paid to make this relationship significant. As a result of this review, it was revealed that not all teachers were able to create valid metaphors. Some answers that do not contain any metaphor sources, where the reason for the metaphor are not presented, the definition of inclusive education is 


\section{Acta Educationis Generalis \\ Volume 11, 2021, Issue 2}

described, or the types of inclusion explained (inclusive education is similar to wind, because .... or inclusive education may be full-time or part-time) were not included in the evaluation. After this elimination, of the 113 preschool teachers participated in the study, the answers given by 101 teachers to the research question in regard with the concept of metaphor were included in the evaluation, these teachers produced 53 different metaphors in regard with the concept of inclusive education. Then, in the third stage, which is the category development phase, 53 valid metaphors developed by preschool teachers were analyzed by gathering them under 9 different categories according to their common characteristics. In the final stage indicated by Saban (2009), the validity and reliability stage of the study was taken into consideration. Expert opinion was consulted for the reliability of the study in order to determine whether the metaphors presented under the conceptual categories obtained represent the relevant category. Two experts in total, one from the department of preschool education and one from the education programs and teaching department, were consulted in regard with all metaphors $(\mathrm{n}=53)$ and categories $(\mathrm{n}=9)$ created and the eligibility of these metaphors placed under the categories to represent the relevant categories was evaluated by making comparisons in accordance with expert opinions. The reliability of the data analysis was calculated using Reliability $=$ Consensus $\backslash$ [Consensus + Disagreement] X 100 formula of Miles \& Huberman (1994) and the reliability value was determined as $90 \%$. Then, percentage (\%) and number of participants (f) were calculated after transferring the data to the computer environment.

\section{Findings}

In this part of the study, the metaphors that preschool teachers developed in regard with the concept of inclusive education were presented below two main titles. These titles are as follows: "Metaphors developed by preschool teachers regarding inclusive education" and "Metaphor categories developed by preschool teachers regarding inclusive education".

Table 1

Metaphors developed by preschool teachers regarding inclusive education

\begin{tabular}{|c|c|c|c|c|c|}
\hline Metaphors Developed & $f$ & $\underline{\%}$ & Metaphors Developed & $f$ & $\underline{\%}$ \\
\hline 1. Garden & 1 & $\overline{0.99}$ & 28. Coincidences & 1 & $0 . \overline{9} 9$ \\
\hline 2. Play dough & 1 & 0.99 & 29. Branch of a tree & 1 & 0.99 \\
\hline 3. Rainbow & 12 & 11.88 & 30. Puzzle & 1 & 0.99 \\
\hline 4. Breath & 1 & 0.99 & 31. Ladder & 1 & 0.99 \\
\hline 5. The Sun & 7 & 6.93 & 32. Light in the dark & 1 & 0.99 \\
\hline 6. Oxygen & 1 & 0.99 & 33. Taking a Step & 1 & 0.99 \\
\hline 7. Choir & 1 & 0.99 & 34. Embroidery & 1 & 0.99 \\
\hline 8. Life Ring & 1 & 0.99 & 35. Music & 1 & 0.99 \\
\hline
\end{tabular}




\begin{tabular}{lcclcl}
\hline 9. Mother & 1 & 0.99 & 36. To Soil & 1 & 0.99 \\
10. Life in a foreign land & 1 & 0.99 & 37. Scale & 1 & 0.99 \\
11. Art & 1 & 0.99 & 38. To Fingers & 2 & 1.98 \\
12. Raising a baby & 8 & 7.92 & 39. Justice & 1 & 0.99 \\
13. The long way & 1 & 0.99 & 40. Unnecessary work & 3 & 2.97 \\
14. Gardener & 10 & 9.90 & 41. Private school & 1 & 0.99 \\
15. Flower & 1 & 0.99 & 42. Compass & 2 & 1.98 \\
16. Water & 2 & 1.98 & 43. Prosthetic foot & 1 & 0.99 \\
17. Game & 1 & 0.99 & 44. Polar star & 1 & 0.99 \\
18. Book & 1 & 0.99 & 45. Stale bread & 1 & 0.99 \\
19. Winter salad & 1 & 0.99 & 46. Mining & 1 & 0.99 \\
20. Iron forging & 1 & 0.99 & 47. Orchestra & 9 & 8.91 \\
21. Freak & 1 & 0.99 & 48. Day and night & 1 & 0.99 \\
22. Dessert & 1 & 0.99 & 49. Seed & 3 & 2.97 \\
23. Salt & 1 & 0.99 & 50. Body organs & 1 & 0.99 \\
24. Life & 1 & 0.99 & 51. Dream & 1 & 0.99 \\
25. Walker & 1 & 0.99 & 52. Rebirth & 1 & 0.99 \\
26. Pen & 1 & 0.99 & 53. Tree & 1 & 0.99 \\
27. Egg & 1 & 0.99 & & & \\
\hline
\end{tabular}

Considering the data given in Table 1, it is seen that preschool teachers created 53 different metaphors in regard with the concept of inclusive education. It is observed that $11.88 \%(\mathrm{f}=12)$ of the respondents participating in the study considered inclusive education similar to a "rainbow". They stated that each color on the rainbow reflects individual differences of the students. It is observed that $9.90 \%(\mathrm{f}=10)$ of the participants considered inclusive education similar to "gardening". Preschool teachers stated that, unlike other education models, inclusive education is a kind of education that requires special attention and sensitivity, like growing a flower. In addition, $8.91 \%(\mathrm{f}=9)$ of the participants considered inclusive education similar to an "orchestra". They emphasized that inclusive education should be in harmony with each other like sounds and music in an orchestra. Apart from these, the most common metaphors used by preschool teachers for inclusive education are as follows: "raising a baby" with $7.92 \%$ (f=8), "sun" 6.93\% ( $\mathrm{f}=7$ ), "seed" $2.97 \%(\mathrm{f}=3)$, " unnecessary work" $2.97 \%$ (f=3), "water" 1.98\% (f=2), "finger" $1.98 \%$ (f=2), "compass" $1.98 \%$ $(\mathrm{f}=2)$, respectively. It is noteworthy that $2.97 \%(\mathrm{f}=3)$ of preschool teachers consider inclusive education as an "unnecessary work".

In Table 2, metaphor categories developed by preschool teachers regarding inclusive education are given. 


\section{Acta Educationis Generalis \\ Volume 11, 2021, Issue 2}

\section{Table 2}

Metaphor categories developed by preschool teachers regarding inclusive education

\begin{tabular}{|c|c|c|c|c|}
\hline Categories & Metaphors & $N$ & $f$ & $\%$ \\
\hline $\begin{array}{l}\text { Inclusive education as } \\
\text { the riches of nature }\end{array}$ & $\begin{array}{l}\text { Rainbow (12), Sun (7), Polar star (1), } \\
\text { Night-Day (1) }\end{array}$ & 4 & 21 & 20.79 \\
\hline $\begin{array}{l}\text { Inclusive education as } \\
\text { the rhythm of art }\end{array}$ & $\begin{array}{l}\text { Art (1), Choir (1), Music (1), Orchestra } \\
\text { (9), }\end{array}$ & 4 & 12 & 11.88 \\
\hline $\begin{array}{l}\text { Indispensable } \\
\text { inclusive education }\end{array}$ & $\begin{array}{l}\text { Water (2), Mother (1), Breath (1), Body } \\
\text { organs (1), Fingers (2), Oxygen (1) }\end{array}$ & 6 & 8 & 7.92 \\
\hline $\begin{array}{l}\text { Inclusive education as } \\
\text { food and drink }\end{array}$ & $\begin{array}{l}\text { Stale bread (1), Winder salad (1), Dessert } \\
\text { (1), Egg (1), Salt (1) }\end{array}$ & 5 & 5 & 4.95 \\
\hline $\begin{array}{l}\text { Inclusive education } \\
\text { depending on soil }\end{array}$ & $\begin{array}{l}\text { Garden (1), Gardener (10), Tree (1), } \\
\text { Branch of a tree (1), Seed (3), Soil (1), } \\
\text { Flower (1) }\end{array}$ & 7 & 18 & 17.82 \\
\hline $\begin{array}{l}\text { Inclusive education as } \\
\text { a tool and equipment }\end{array}$ & $\begin{array}{l}\text { Life ring (1), Walker (1), Pen (1), Book } \\
\text { (1), Puzzle (1), Ladder (1) Scale (1), } \\
\text { Compass (2), Prosthetic foot (1), Play } \\
\text { dough (1), Embroidery (1) }\end{array}$ & 11 & 12 & 11.88 \\
\hline $\begin{array}{l}\text { Inclusive education as } \\
\text { a work and living area }\end{array}$ & $\begin{array}{l}\text { Raising a baby (8), Life in a foreign land } \\
\text { (1), Iron forging (1), Life (1), Private } \\
\text { school (1), Mining (1), Game (1) }\end{array}$ & 7 & 14 & 13.86 \\
\hline $\begin{array}{l}\text { Inclusive education as } \\
\text { other expressions }\end{array}$ & $\begin{array}{l}\text { Coincidences (1), Light in the dark (1), } \\
\text { Taking a Step (1), Dream (1), Justice (1), } \\
\text { Rebirth (1), Long way (1) }\end{array}$ & 7 & 7 & 6.93 \\
\hline $\begin{array}{l}\text { Inclusive education as } \\
\text { an expression of } \\
\text { negativity }\end{array}$ & Freak (1), Unnecessary work (3) & 2 & 4 & 3.97 \\
\hline Total & 9 & 53 & 101 & 100.00 \\
\hline
\end{tabular}

According to the data given in Table 2, the metaphors developed by preschool teachers for the concept of inclusive education were gathered in 9 different categories. These categories are as follows: (1) "Inclusive education as the riches of nature", (2) "Inclusive education as the rhythm of art", (3) "Indispensable inclusive education", (4) "Inclusive education as food and drink", (5) "Inclusive education depending on soil", (6) "Inclusive education as a tool and equipment", (7) "Inclusive education as a work and living area", (8) "Inclusive education as other expressions", (9) "Inclusive education as an expression of negativity", respectively. Furthermore, 21 teachers developed 4 different metaphors in the category of "inclusive education as the riches of nature". It was also determined that 12 teachers developed 7 different metaphors in the category of "inclusive education as the rhythm of art", 8 teachers developed 6 different metaphors in the category of "indispensable inclusive education", 5 teachers developed a total of 5 different metaphors in the category of "inclusive education as food and 
drink", 18 teachers developed 7 different metaphors in the category of "inclusive education depending on soil", 12 teachers developed 11 different metaphors in the category of "inclusive education as a tool and equipment", 14 teachers developed 7 different metaphors in the category of "inclusive education as a work and living area", 7 teachers developed 7 different metaphors in the category of "inclusive education as other expressions", and lastly, 4 teachers developed 2 different metaphors in the category of "inclusive education as an expression of negativity", respectively.

\subsection{Category 1. Inclusive Education as the Riches of Nature}

Considering the data given in Table 2, it is observed that various metaphors, such as rainbow (12), sun (7), polar star (1), night-day (1) were developed by preschool teachers in regard with inclusive education under this category. In addition, this category stands out as the category, in which the maximum number of metaphors (f: 21) was developed by teachers. Sample metaphor expressions developed by teachers related to this category are given below.

"It is similar to rainbow colours. Because each colour is beautiful by itself, but colours making up the rainbow are amazing when they come together." (T10)

"It is similar to the sun, because the sun treats everyone equally." (T2)

"Inclusive education is like a pole star, because it guides people." (T38)

"Inclusive education is like night and day. Because both are like equal halves of each other." (T60)

\subsection{Category 2. Inclusive Education as the Rhythm of Art}

A total of 12 participants developed 4 different metaphors for the concept of inclusive education under this category. This category consists of metaphors, such as orchestra (9), art (1), music (1), choir (1) respectively. Sample metaphor expressions developed by teachers related to this category are given below.

"Inclusive education is like an orchestra. Because different musical instruments come together and form a harmonious whole in an orchestra as in inclusive education." (T123)

"Inclusive education is like art; it gives society new works of art in different fields." (T49)

"Inclusive education is like the sound of music coming from far away. You will hear it if you listen devotionally." (T50)

"Inclusion education is similar to choir, because it is like a beautiful song created by combining different voices." (T66)

\subsection{Category 3. Indispensable Inclusive Education}

Under this category, participants developed 6 different metaphors regarding the game concept. This category consists of metaphors, such as water (2), finger (2), mother (1), breath (1), body organs (1), oxygen, respectively. Sample metaphor expressions developed by teachers related to this category are given below. 
"It is like giving water because the inclusion student needs attention and love." (T112)

"Children are like the fingers of a hand; they are all in different sizes. But each of them is part of a wholeness." (T5)

"Inclusive education is similar to mother; because this education is like a mother's bosom." (T94)

"Inclusive education is like the organs of a body; because every individual that makes up the society is like the organs of the body." (T17)

\subsection{Category 4. Inclusive Education as Food and Drink}

Under this category, 5 participants developed 5 different metaphors for the concept of inclusive education. This category consists of metaphors, such as stale bread (1), winter salad (1), dessert (1), egg (1), salt (1), respectively. Sample metaphor expressions developed by teachers related to this category are given below.

"Inclusive education is like using stale breads, because stale bread is not like fresh bread." (T28)

"Inclusive education is like winter salad, because you can find something in every colour in it." (T35)

"Inclusive education is like an egg; the shell is hard, but inside is very precious and delicious." (T88)

\subsection{Category 5. Inclusive Education Depending on Soil}

Under this category, 18 participants developed 7 different metaphors regarding the concept of inclusive education. This category consists of metaphors, such as gardener (10), seed (3), garden (1), soil (1), tree (1), tree branch (1), flower (1), respectively. Sample metaphor expressions developed by teachers related to this category are given below.

"Inclusive education is like gardening, because it is essential to combine different flowers and create a beautiful whole." (T96)

"It is similar to the seed sown in the field, because effort spent and patience is needed to get the product." (T20)

"If inclusive education is considered as the society itself, it is like branch of a tree; because it also a part of society." (T105)

\subsection{Category 6. Inclusive Education as a Tool and Equipment}

Under this category, 12 participants developed 11 different metaphors regarding the concept of inclusive education. This category consists of metaphors, such as compass (2), life ring (1), walker (1), book (1), pen (1), puzzle (1) scale (1), prosthetic foot (1), ladder (1), play dough (1), and embroidery (1), respectively. Sample metaphor expressions developed by teachers related to this category are given below. 


\section{Acta Educationis Generalis \\ Volume 11, 2021, Issue 2}

"Inclusive education is like a compass. Because our student is like a ship in a storm. Inclusive education guides him like a compass." (T30)

"It is like a life ring, which gives a student, who looks very normal from the outside, the opportunity to breathe in the classroom." (T44)

"Inclusive education is like a walker; because it ensures that the first steps are taken to adapt to society." (T59)

"Inclusive education is like a ladder; because it is like a step that provides the connection between the floors in the building." (T85)

"Inclusive education is like a prosthetic foot, because the prosthetic foot is like the real foot for those who need it". (T8)

\subsection{Category 7. Inclusive Education as a Work and Living Area}

Under this category, 14 participants stated that they consider inclusive education similar to 7 different metaphors. This category consists of metaphors, such as raising a baby (8), living in a foreign land (1), iron forging (1), life (1), private school (1), game (1), mining (1), respectively. Sample metaphor expressions developed by teachers related to this category are given below.

"Inclusive education is like raising a baby. Because it is a challenging journey that requires constant attention and love." (T30).

"Inclusive education is like searching for a precious metal hundreds of meters below the ground; because inclusive education is like finding the ore hidden in the soil." (T75)

"Inclusion education is like iron forging; because it is like fire that either melts or makes it an envy for everyone." (T67)

\subsection{Category 8. Inclusive Education as Other Expressions}

Under this category, 7 participants stated that they consider inclusive education similar to 7 different metaphors. This category consists of metaphors, such as coincidences (1), light in the dark (1), taking a step (1), dream (1), justice (1), rebirth (1), long way (1), respectively. Sample metaphor expressions developed by teachers related to this category are given below.

"Inclusive education is like light in the dark. Because the child provided with inclusive education is like a person lost his way in the dark. The inclusive education guides him by shedding light on his way." (T100)

"Inclusive education is justice; because it offers everyone the same opportunities." (T11)

"It is like taking another step, because you learn something new every day with every step." (T19)

\subsection{Category 9. Inclusive Education as an Expression of Negativity}

Under this category, 4 participants developed 2 different metaphors regarding the concept of inclusive education. This category consists of metaphors, such as 
unnecessary work (3) and freak (1), respectively. Sample metaphor expressions developed by teachers related to this category are given below.

"It is like rowing in vain for an unnecessary work; because it is like writing on water." (T6)

"It is like a freak; because it makes no sense. The fact that educating someone, who needs to be educated in a special classroom, in the normal classroom is like pouring garlic yogurt on a sweet pastry with nuts." (T23)

\section{Discussion}

Even though the view that specialization and special planning is important in the education of children, who need special education, in recent times remains valid, it is increasingly accepted that they should be educated in a regular educational environment with their peers instead of completely separating them from normal children (Aral, 2011). This practice, which is called inclusive education, includes providing support education services to individuals with special needs, who are affected by disability for any reason, and ensuring that they receive education with their normal peers (De Boer, Pijl, \& Minnaert, 2010).

This research was carried out with preschool teachers. In this context, it was determined that preschool teachers developed 53 different metaphors in regard with the concept of inclusive education. Of the 113 preschool teachers participated in the study, the answers given by 101 teachers to the research question were included in the evaluation. In line with the data obtained in this research, considering the distribution of metaphors developed by preschool teachers regarding the concept of "inclusive education" by categories, the following categories take the first three places: inclusive education as the riches of nature $(20.79 \%)$, inclusive education depending on the soil $(17.82 \%)$ and lastly, inclusive education as a work and living area (13.86\%), respectively.

The category of inclusive education as the riches of nature is represented by the metaphors of "the rainbow, sun, polar star, day-night". However, the "rainbow" metaphor draws attention as the most developed metaphor by the participants in all categories. In line with the results of this study, it is possible to say that a significant proportion of preschool teachers see the individual differences of children as richness, just like the colours of the rainbow, and they think that inclusive education can guide and enlighten their paths for children who need this education.

The category of inclusive education depending on the soil is represented by the metaphors of "gardener, seed, tree, branch of tree, soil, flower, garden". Based on these results, it is possible to say that preschool teachers consider inclusive education in this category as an educational model that requires attention and patience and needs someone else's help.

The category of inclusive education as a work and living area is represented by the metaphors of "raising a baby, living in a foreign land, iron forging, life, private school, mining, games". Based on these results, it is seen that preschool 
teachers state that inclusive education in this category is a process that requires attention, continuity and patience.

It is observed that inclusive education as the riches of nature, inclusive education depending on soil and inclusive education as a work and living area include most of the metaphors, which are followed by inclusive education as the rhythm of art $(11.88 \%)$, inclusive education as a tool and equipment (11.88\%), indispensable inclusive education (7.92\%), inclusive education as other expressions $(6.93 \%)$, inclusive education as food and drink (4.95\%) and inclusive education as an expression of negativity, respectively.

The category of inclusive education as the rhythm of art is represented by the metaphors of "art, choir, music, orchestra". It is possible to say that preschool teachers draw attention to inclusive education in this category, which has some aspects that add voice and breath to the lives of children, who need this education, and facilitate their adaptation to real life, under this category.

The category of inclusive education as a tool and equipment is represented by the metaphors of "compass, life ring, walker, pen, book, puzzle, ladder, scale, prosthetic foot, play dough, embroidery". In line with these results, it is possible to say that preschool teachers define inclusive education in this category as a difficult and long journey that comes to life in the hands of teachers, and that they emphasize that this education model should be implemented regularly and balanced by the teachers despite its complexity.

The category of indispensable inclusive education is represented by the metaphors of "water, finger, mother, breath, body organs, oxygen". Preschool teachers stated that they think that inclusive education in this category is a basic need for children, who need this education, and receiving educational services with their peers is an indispensable requirement for them.

The category of inclusive education as other expressions is represented by the metaphors of "coincidences, light in the dark, taking a step, dream, justice, rebirth, long way". Based on these results, preschool teachers stated that inclusive education in this category is a difficult process that develops a sense of equality and justice among people, but even partially its quality depends on chance and coincidence.

The category of inclusive education as food and drink is represented by metaphors of "stale bread, winter salad, dessert, egg, salt". Based on these results, it is possible to say that preschool teachers consider inclusive education as a value that adds taste and meaning to the lives of children who need this education.

The category of inclusive education as an expression of negativity is represented by the metaphors of "unnecessary work, freak". Based on these results, it is possible to say that some of the preschool teachers have negative judgments about inclusive education. This may be due to the negative situations that some of the teachers have encountered before or they do not have sufficient knowledge and equipment about inclusive education. When the relevant 


\section{Acta Educationis Generalis \\ Volume 11, 2021, Issue 2}

literature was examined, it was determined that there are studies with similar results supporting the results of this research (Yazıc1-Nur \& Akman, 2017; Gezer-Seçkin, 2017; Koçyiğit, 2015; Sucuoğlu et al., 2014; Bozkurt, 2013). In addition, Fayez, Dababneh and Jumiaan (2011), and Zelina (2020) emphasized the need for structures that contain more practices to strengthen inclusive teaching skills of preschool teachers focusing on early childhood in order to realize inclusive education applications.

\section{Conclusion and suggestions}

Based on the results of this research, the following suggestions can be made on the subject. Based on the conclusion that some of the preschool teachers have a negative perception about inclusive education, teachers can be given seminars to increase their awareness and education levels regarding inclusive education through in-service training courses. Based on the result of the fact that inclusive education is a fundamental need for children with special needs in need of this education, the number of scientific studies can be increased in order to improve the quality of inclusive education and change the progress of this education, which partially depends on chance and coincidence. Providing undergraduatelevel courses to teachers, who will shape their learning lives related to inclusive education, during pre-service training periods can be an important step towards the future of the issue.

\section{References}

Akgün E. (2016). Okul öncesi öğretmen adaylarının "çocuk" ve "okul öncesi öğretmeni” kavramına ilişkin metaforik algıları. Abant İzzet Baysal Üniversitesi Eğitim Fakültesi Dergisi, 16(4), 1652-1672.

Aral, N. (2011). Okul öncesi eğitimde kaynaştırma. İstanbul: Morpa Kültür Yayınları.

Batu, S., \& Kırcaali- İftar, G. (2007). Kaynaştırma. Ankara: Kök Yayıncılık.

Bender, W. N., Vail, C. O., \& Scott, K. (1995). Teachers' attitudes toward increased mainstreaming: Implementing effective instruction for students with learning disabilities. Journal of Learning Disabilities, 28(2), 87-94.

Barnová, S., \& Tamášová, V. (2018). Risk and protective factors in the life of youth in relation to resilience. Psychológia a patopsychológia diet'at'a, 52(1), 50-59. https://doi.org/10.2478/ papd-2018-0001

Bozkurt, A. (2013). Okul öncesi kaynaştırma ĕgitimine ilişkin öğretmenlerin tutumlarının incelenmesi. (Unpublished Master thesis). İstanbul: Okan Üniversitesi Sosyal Bilimler Enstitüsü.

Büyüköztürk, Ş., Çakmak, E. K., Akgün, Ö. E., Karadeniz, Ş., \& Demirel, F. (2011). Bilimsel araştırma yöntemleri. Ankara: Pegem Yayınları.

Corbett, J. (2001). Supporting Inclusive Education: A Connective Pedagogy. London: Routledge Falmer.

Creswell, J. W. (2007). Qualitative Inquiry \& Research Design Choosing among Five Approaches. Sage Publications. 


\section{Acta Educationis Generalis \\ Volume 11, 2021, Issue 2}

De Boer, A. A., Pijl, S. J., \& Minnaert, A. (2010). Attitudes of parents towards inclusive education: A review of the literature. European Journal of Special Needs Education, 25(2), 165-181.

Dede, Ş. (1996). Özel eğitim hakkında Salamanca Bildirisi. Özel Eğitim Dergisi, 2(2), 91-94.

Diken, I. H., Rakap, S., Diken, O., Tomris, G., \& Celik, S. (2016). Early childhood inclusion in Turkey. Infants \& Young Children, 29(3), 231-238.

Drakenberg, M., \& Malmgren, T. V. (2012). Basic values: are curriculum ideas being realised? A metaphor analysis. Citizenship, Social and Economics Education, 11(2), 118-128.

Duran, A., \& Dağlıŏglu, E. H. (2017). Okul öncesi öğretmen adaylarının üstün yetenekli çocuklara ilişkin metaforik algıları. GEFAD/GUJGEF, 37(3), 855-881.

EHİS, (2011). Birleşmiş Milletler Engellilerin Haklarına İlişkin Sözleşme. Retrieved from $\mathrm{http} / /$ www2.ohchr.org/english/law/disabilities-convention. $\mathrm{htm}$

ERG. (2011). Kaynaştırma/bütünleştirme yoluyla eğitimde Dünyadan ve Türkiye'den iyi örnekler. İstanbul: Ĕ̆itim Reformu Girişimi.

Fayez, M. M. O., \& Dababneh, K., \& Jumiaan, I. F. (2011). Preparing teachers for inclusion: Jordanian preservice early childhood teachers' perspectives. Journal of Early Childhood Teacher Education, 32(4), 322-337. https://doi.org/10.1080/10901027.2011.622239

Gampel, H. D, Gottlieb, J., \& Harrison, H. R. (1974). Comparison of classroom behavior of specialclass. EMR. Integrated EMR, Low 10 and Nonretarded Children. American Journal of Mental Deficiency, 79(I), 16-21.

Gezer-Seçkin, M. (2017). Sinıfinda kaynaştırma öğrencisi bulunan okul öncesi öğretmenlerinin kaynaştırma eğitimine yönelik rol algılarının belirlenmesi. (Unublished Master thesis). Eskişehir: Anadolu Üniversitesi Eğitim Bilimleri Enstitüsü.

Giren., S., \& Durak, E. (2015). Okul öncesi öğretmenlerinin oyuncak kavramına ilişkin metaforik algıları. Bartın Üniversitesi Eğitim Fakültesi Dergisi, 4(2), 561-575.

Goldstein, L. B. (2005). Becoming a teacher as a hero's journey. Using metaphor in preservice teacher education. Teacher Education Quarterly, 32(1), 7-24.

Guerrero, M., \& Villamil, O.S. (2002). Metaphorical conceptualizations of ESL teaching and learning. Language Teaching Research, 6(2), 95-120.

Guralnick, M. J. (2001). A framework for change in early childhood inclusion. In M. J. Guralnick (Ed.), Early childhood inclusion: Focus on change (pp. 3-35). Baltimore: Brookes.

Gürgür, H., \& Hasanoğlu-Yazçayır, G. (2019). Türkiye'de kaynaştırma eğitimine yönelik öğretmenlerin görüşlerine odaklanılmış lisansüstü eğitim tezlerinin sentezlenmesi: metaetnografik bir çalışma. Eğitimde Nitel Araşstırmalar Dergisi, Journal of Qualitative Research in Education, 7(2), 845-872.

Hannu, S., Petra, E., Mirna, N., \& Olli-Pekka, M. (2012). Understanding teachers' attitudes and self-efficacy in inclusive education: Implications for pre-service and in-service teacher education. European Journal of Special Needs Education, 27(1), 51-68.

Inclusion International. (2009). Better Education for All: When We're Included Too. Salamanca: Instituto Universitario de Integracion en la Comunidad (INICO). Retrieved from http://www.inclusiveeducation.ca/documents/ BetterEdAllBOOK.pdf

Karadeniz, G. (2002). Eğitimde kaynaştırma. (Unpublished Master thesis). İstanbul: Maltepe Üniversitesi.

Kargın, T. (2004). Kaynaştırma: tanımı, gelişimi ve ilkeleri. Ankara Üniversitesi Eğitim Bilimleri Fakültesi Özel Ĕ̈itim Dergisi, 5(2) 1-13.

Koçyiğit, S. (2015). Ana sınıflarında kaynaştırma eğitimi uygulamalarına ilişkin öğretmen-rehber öğretmen ve ebeveyn görüşleri. Uluslararası Türkçe Edebiyat Kültür Eğitim Dergisi. 4(1), $391-415$.

Lakoff, G., \& Johnson, M. (2010). Metaforlar: hayat, anlam ve dil. İstanbul: Paradigma.

Metin, N. (1992). Okul öncesi dönemde özürlü çocuklar için kaynaştırma programları. Özel Ĕgitim Dergisi, 1(2), 32-36. 


\section{Acta Educationis Generalis \\ Volume 11, 2021, Issue 2}

Miles, M. B., \& Huberman, A. M. (1994). Qualitative data analysis: An expanded sourcebook. (2nd Edition). California: SAGE Publications.

Mitchell, D. (2008). What really works in special and inclusive education: Using evidence-based teaching strategies. Abingdon, Oxfordshire: Routledge.

Odom, L. S., \& McEvoy, A, M. (1990). Mainstreaming at the preschool level: Potential barriers and tasks for the field. Topics in Early Childhood Special Education, 10(2), 48-61. https://doi.org/10.1177/027112149001000205

Oğuzkan, Ş., \& Oral, G. (1995). Okul öncesi eğitimi. Eskişehir: Anadolu Üniversitesi Eğitim Fakültesi Yayınları.

Opp, G., \& Thurmair, M. (1993). Early intervention for children with developmental delays and children with disabilities: The Bavarian concept. Topics in Early Childhood Special Education, 13(4), 488- 507.

Özdemir, H. (2010). Okul öncesi öğretmenlerinin kaynaştırma uygulamasına iliş̧kin görüşlerinin incelenmesi. (Unpublished Master thesis). Edirne: Trakya Üniversitesi, Sosyal Bilimler Enstitüsü.

Saban, A. (2008). Okula ilişkin metaforlar. Kuram ve Uygulamada Eğitim Yönetimi, 55, 459-496.

Saban, A. (2009). Öğretmen adaylarının öğrenci kavramına ilişkin sahip oldukları zihinsel imgeler. Türk Ĕ̈itim Bilimleri Dergisi, 7(2), 281-326.

Salisbury, C. L. (1990). The least restrictive environment: Understanding the Options. Policy and Practice in Early Childhood Special Education Series. Washington, DC: Department of Education.

Salisbury, L. C. (1991). Mainstreaming during the early childhood years. Exceptional Children. $58(2), 146-155$.

Sazak-Pınar, E. (2006). Dünyada ve Türkiye'de erken çocukluk özel eğitiminin gelişimi ve erken çocukluk özel eğitim uygulamaları. Ankara Üniversitesi Eğitim Bilimleri Fakültesi Özel Ĕ̈itim Dergisi, 7(2), 71-83.

Stockton, S. (2017). Math Is Alive: The Metaphor of Living School Disciplines and Some of the Educational Implications. Faculty of Education University of Manitoba.

Sucuoğlu, B., \& Kargın, T. (2010). Illköğretimde kaynaştırma uygulamaları. Ankara: Kök Yayınevi.

Sucuoğlu, B., Karasu-İş̧̧en, F., Bakkaloğlu, H., Demir, Ş., \& Akalın, S. (2014). Okul öncesi ögretmenlerinin kaynaştırmaya ilișkin bilgi düzeyleri. Kuram ve Uygulamada Eğitim Bilimleri, 14(4), 1467-1485.

Talas, S. (2017). Okul öncesi öğretmen adaylarının kaynaştırma öğrencisi kavramına ilişkin algilarının metafor analizi yoluyla incelenmesi. Journal of International Management, Educational and Economics Perspectives, 5(2), 34-44.

Tannehill, D., \& MacPhail, A. (2014). What examining teaching metaphors tells us about preservice teachers' developing beliefs about teaching and learning. Physical Education and Sport Pedagogy, 19(2), 149-163.

Tideman, M. (2015). Education and support for people with intellectual disabilities in Sweden: Policy and practice. Research and Practice in Intellectual and Developmental Disabilities, 2(2), 116-125.

Uçuş, Ș. (2016). Sınıf öğretmeni adaylarının ve okul öncesi öğretmeni adaylarının özel eğitime ilişkin metaforik algılarının incelenmesi. Adlyaman University Journal of Educational Sciences, 6(2), 360-388.

Wehmeier, S. (1993). Oxford Wordpower Dictionary. Oxford: Oxford University Press.

Yazıcı-Nur. D., \& Akman, B. (2017). Okul öncesi öğretmenlerinin otizmli çocukların kaynaştırılması hakkındaki düşüncelerinin incelenmesi. Ankara Üniversitesi Eğitim Bilimleri Fakültesi Özel Eğitim Dergisi, Elektronik Yayın. https://doi.org/10.21565/ ozelegitimdergisi.284253 


\section{Acta Educationis Generalis \\ Volume 11, 2021, Issue 2}

Yazıcı, E., Çelik, M., Nur-Yıldırım., F., Altıntaş, E., \& Güneş, A. (2018). Okul öncesi dönemdeki çocukların okul kavramına ilişkin metaforik algıları. Sakarya Üniversitesi Eğitim Fakültesi Dergisi, 35, 64-86.

Yıldırım, A., \& Şimşek, H. (2011). Sosyal bilimlerde nitel araştırma yöntemleri. Ankara: Seçkin Yayınc1lik.

Zelina, M. (2020). Interviews with Teachers about Inclusive Education. Acta Educationis Generalis, 10(2), 95-111. https://doi.org/10.2478/atd-2020-0012

Zembat, R., İlknur-Tunçeli, H., \& Akşin, E. (2015). Okul öncesi öğretmen adaylarının "okul yöneticisi" kavramına ilişkin algılarına yönelik metafor çalışması. Hacettepe Üniversity Faculty of Healty Sciences Journal, 1(2), 446-459. 